\title{
Reduction of sternal wound infections in diabetic patients undergoing off-pump coronary artery bypass surgery and using modified pedicle bilateral internal thoracic artery harvest technique
}

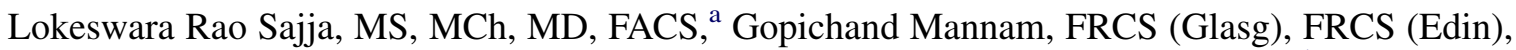 \\ FRCS (CT), ${ }^{a}$ Satya Bhaskara Raju Dandu, MS, MCh, ${ }^{a}$ and Sriramulu Sompalli, MD ${ }^{\mathrm{b}}$
}

\begin{abstract}
Objective: We compared sternal wound infections between diabetic patients undergoing off-pump coronary artery bypass surgery using bilateral internal thoracic artery grafting or single internal thoracic artery grafting and nondiabetic patients receiving bilateral internal thoracic artery or single internal thoracic artery grafting using a modified pedicled harvest technique of internal thoracic artery.
\end{abstract}

\begin{abstract}
Methods: This retrospective study was conducted to analyze the data from 3072 patients who underwent primary coronary artery bypass surgery using an off-pump technique from August 2004 to October 2010. Of the 1211 diabetic patients, 181 received bilateral internal thoracic artery grafts (group 1) and 1030 received single internal thoracic artery grafts (group 2). Of the 1861 nondiabetic patients, 161 received bilateral internal thoracic artery grafts (group 3) and 1700 received single internal thoracic artery grafts (group 4). The incidence of postoperative sternal wound infections in diabetic patients who received bilateral internal thoracic artery grafting was compared with the incidence in other groups (group 2, 3, and 4). A modified technique of pedicled harvesting of the internal thoracic artery was done in patients receiving bilateral internal thoracic artery grafting, and a standard pedicled harvest was used in patients receiving single internal thoracic artery grafts.
\end{abstract}

Results: No significant differences were present in the preoperative variables among the groups. The observed rate of superficial sternal wound infections in groups 1,2,3, and 4 was $1.1 \%$ (2 patients), $1.65 \%$ (17 patients), $1.86 \%$ (3 patients), and $1.65 \%$ (28 patients), respectively $(P=.9941)$. Deep sternal infections were observed in $1(0.55 \%), 5(0.48 \%), 1(0.62 \%)$, and 14 patients $(0.82 \%)$ in groups 1 through 4 , respectively $(P=.8380)$. Multivariate analysis showed that bilateral internal thoracic artery harvesting $(P=.889)$, diabetes mellitus $(P=.96)$, and patient age were not predictors of sternal wound infection.

Conclusions: The results of the present study show that there is no increase in the incidence of sternal wound infections in diabetic patients undergoing coronary artery bypass surgery with bilateral internal thoracic artery grafting by using a modified pedicle bilateral internal thoracic artery harvesting technique with sparing of the communicating bifurcation of internal thoracic artery to the chest wall and preservation of pericardiacophrenic artery branch. (J Thorac Cardiovasc Surg 2012;144:480-5)

\begin{abstract}
The use of the left internal thoracic artery (LITA) as a bypass graft to the left anterior descending artery has been proved to provide superior early and late survival and better eventfree survival after coronary artery bypass grafting $(\mathrm{CABG}){ }^{1}$ There is also increasing evidence that patients who receive bilateral internal thoracic artery (BITA) grafts have better long-term outcomes than those receiving single ITA (SITA) grafts. ${ }^{2-6}$ The routine use of BITA grafting in coronary revascularization has been resisted by several
\end{abstract}

From the Divisions of Cardiothoracic Surgery ${ }^{\mathrm{a}}$ and Cardiothoracic Anesthesiology, ${ }^{\mathrm{b}}$ Star Hospitals, Banjara Hills, Hyderabad, India.

Disclosures: Authors have nothing to disclose with regard to commercial support. Received for publication Oct 10, 2011; revisions received Feb 1, 2012; accepted for publication March 12, 2012; available ahead of print April 12, 2012.

Address for reprints: Lokeswara Rao Sajja, MS, MCh, MD, FACS, Division of Cardiothoracic Surgery, Star Hospitals, Road No. 10, Banjara Hills, Hyderabad 500034, AP, India (E-mail: sajjalr@yahoo.com).

$0022-5223 / \$ 36.00$

Copyright (c) 2012 by The American Association for Thoracic Surgery doi:10.1016/j.jtcvs.2012.03.024 surgeons for multiple reasons. BITA grafting increases the difficulty and duration of the operation and is technically challenging. The most real, persistent, and serious objection to BITA grafting has been an increased risk of sternal wound complications, an observation that has often been cited as a reason to avoid BITA grafting. ${ }^{7,8}$

Multiple retrospective clinical studies of patients undergoing CABG have documented an increased risk of sternal wound complications associated with BITA grafting, and a few studies have specially identified diabetes as a factor associated with a greatly increased risk, leading to restriction of the use of the BITA grafting technique to $4 \%$ to $5 \%$ of CABG procedures. $^{7-10}$ Compared with SITA grafting in patients with diabetes, BITA grafting might be of particular benefit for those with severe and diffuse coronary artery disease.

The increased risk of sternal wound complications appears to be caused by the sternal ischemia occurring after BITA harvesting. Anatomic studies have predicted a decrease in sternal blood flow resulting from BITA dissection, and this has been 


\section{Abbreviations and Acronyms \\ BITA = bilateral internal thoracic artery \\ BMI = body mass index \\ $\mathrm{CABG}=$ coronary artery bypass grafting \\ ITA = internal thoracic artery \\ LITA $=$ left internal thoracic artery \\ RITA $=$ right internal thoracic artery}

confirmed by postoperative flow studies, with the flow further reduced after BITA grafting than after SITA grafting. ${ }^{11-14}$

Traditionally, the ITA has been dissected as a pedicle that includes the artery and accompanying veins, endothoracic fascia, and a part of the parietal pleura and, distally, the transversus thoracis muscle. Electrocautery has been used to divide the branches after the application of clips on the artery side. Several techniques have been developed to reduce the sternal ischemia after ITA dissection. A skeletonizing technique of the ITA harvest is 1 such method in which the ITA is dissected as an isolated artery rather than as a pedicle, and electrocautery is usually avoided. ${ }^{9,15}$

An anatomic study has shown that some of the sternal branches and anterior intercostal arteries of the ITA can arise from the ITA as a common trunk. If these common trunks are preserved during ITA dissection, the sternal collateral blood supply might improve after ITA dissection. ${ }^{16}$ Another clinical study using technetium- $99 \mathrm{~m}$ methylene disphosphate bone scanning and single photon emission computed tomography showed that dissecting the LITA as a pedicle graft reduced blood flow to the sternum more than did dissecting the ITA in a skeletonized fashion. ${ }^{17}$

However, the promotion of a collateral blood supply to the sternum after ITA harvest and a reduction in sternal wound infection by preserving the communicating bifurcation of the ITA to the chest wall and the pericardiacophrenic artery branch of the ITA during BITA harvesting has not been evaluated. The present study was conducted to evaluate the effect of preserving the pericardiacophrenic artery of the ITA and communicating musculophrenic and superior epigastric artery branches to the chest wall on the incidence of postoperative sternal wound infections.

\section{METHODS}

In the present retrospective study, we analyzed the data from 3072 consecutive patients (1211 patients with and 1861 patients without diabetes) who underwent primary CABG using an off-pump technique with either BITA or SITA grafts at our institution from August 2004 to October 2010. The institutional ethics committee approved the present study and individual patient consent was waived. BITA harvesting was done using a modified pedicled technique for all patients who received BITA grafts during CABG. Of the 1211 diabetic patients who underwent primary CABG, 181 received BITA grafts (group 1) and 1030 received SITA grafts (group 2). Of the 1861 nondiabetic patients who underwent CABG, 161 received BITA grafts (group 3) and 1700 patients received SITA grafts (group
4). Saphenous vein grafts and radial artery grafts were used as additional bypass conduits as required to achieve complete revascularization. Patients who underwent concomitant cardiac or extracardiac procedures were excluded from the present study.

The criteria for defining a surgical site infection were according to the Centers for Disease Control guidelines. A sternal wound infection was considered superficial if only the skin and subcutaneous tissue were involved, deep when the infection reached the sternum but did not involve it, and organ/space when sternal osteomyelitis or mediastinitis occurred.

\section{Harvesting Technique of ITA}

On the morning of surgery, the hair overlying the potential surgical sites was removed from all patients by shaving followed by an antiseptic wash with betadine. In addition, a complete surgical scrub of the chest and potential donor graft sites was performed with a $5 \%$ povidone-iodine soap solution in the operating room, followed by $10 \%$ povidone-iodine clear solution. An iodoform-impregnated adhesive plastic sheet (Ioban; 3M Health Care, St. Paul, Minn) was routinely applied to the chest and other potential donor graft sites. Intravenous cephazoline was given to all patients ( $1 \mathrm{~g}$ for patients weighing $\leq 60 \mathrm{~kg}$ and $2 \mathrm{~g}$ for patients weighing $\geq 61 \mathrm{~kg}$ ), and additional vancomycin ( $1 \mathrm{~g})$ was administered to patients undergoing BITA harvesting 30 minutes before skin incision. Additional vancomycin, $1 \mathrm{~g}$ intravenously twice daily, was given to the patients in the BITA harvest group because of the historically greater incidence of sternal wound infections in CABG patients who underwent BITA grafting, particularly diabetic patients. The skin was incised with a scalpel, and electrocautery was used to open the presternal layers and pericardium. A median sternotomy was performed in all patients, and bone wax was used sparingly.

The LITA was harvested first. A self-retaining ITA retractor was used for exposure of the ITA bed. A modified sternal retractor providing simultaneous upward pull on the left and downward push on the right hemisternum was used. The parietal pleura and loose connective tissue with accompanying fat was pushed away from the chest wall. The left pleural space was entered and widely opened, allowing easier exposure of the ITA throughout its course. The operating table was rotated to the patient's left, and decreasing the patient's tidal volume aided in the visualization of the mammary bed. The endothoracic fascia was incised both medially and laterally to the ITA, usually about $1 \mathrm{~cm}$ in width. The ITAs were dissected as pedicles from the thoracic wall, along with accompanying internal thoracic veins, endothoracic fascia, and transversus thoracis muscle using low-strength electrocautery (20-25 W). The graft was mobilized distally from the bifurcation of the ITA to the inferior border of the subclavian vein proximally. The arterial side branches were controlled proximally with small hemoclips and distally with electrocautery. The pericardiacophrenic branch, which arises from the ITA in $90 \%$ of patients, was identified and preserved. The sternal branches, perforating branches, and anterior intercostal arteries can arise from the ITA as isolated branches or as a single trunk of all 3 branches or trunks of the sternal and anterior intercostal branches and sternal and perforating branches. When present, these common trunks were dissected and clipped close to the ITA so that the continuity of the sternal and perforator branches or sternal and anterior intercostal arteries were preserved by dividing these trunks just distal to the ligature clips (Figure 1) After completion of LITA harvest, the right ITA (RITA) was harvested in a similar fashion. The right pleural space was also widely opened during RITA harvesting. Transection of ITA was usually done $1 \mathrm{~cm}$ proximal to the bifurcation of the ITA into terminal branches, so that the communication between the musculophrenic and superior epigastric arteries was maintained in the stump of the pedicle, which was left in situ to the chest wall (Figure 2). The ITAs were transected after systemic heparinization.

\section{Surgical Technique of Off-Pump Coronary Artery Bypass}

All patients underwent surgery by way of a median sternotomy. The ITA grafts were harvested as pedicles, as described previously. The additional 


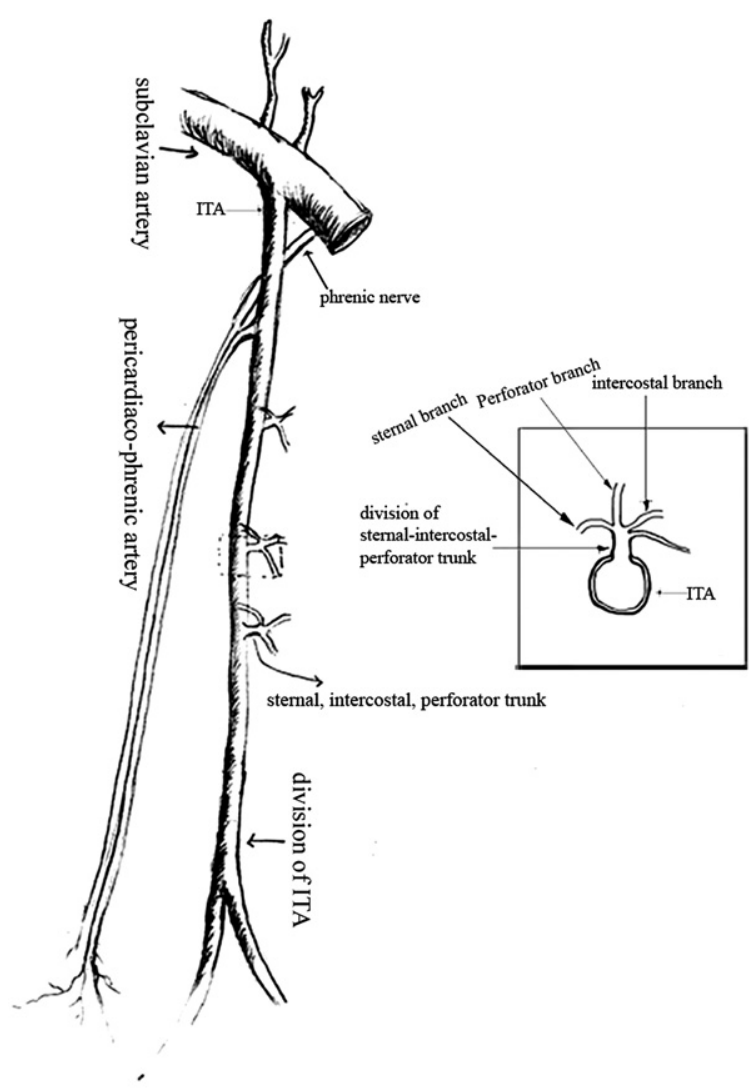

FIGURE 1. Diagrammatic depiction of internal thoracic artery (ITA) and its branches and site for division of ITA.

saphenous vein grafts were harvested using open technique, and radial artery grafts were harvested using the extrafascial technique. The LITA and RITA were used either as in situ pedicled grafts or LITA and RITA "Y" grafts. When the LITA and RITA "Y" graft was used, the composite graft was constructed by anastomosing the RITA as a free graft to the in situ LITA. The free RITA was anastomosed to LITA in an end-to-side fashion using 8-0 polypropylene continuous suture. These anastomoses were constructed over an ITA anastomotic platform mounted on the sternal spreader (Figure 2), as described previously. ${ }^{18}$

The distal anastomoses of the ITA grafts were constructed using 8-0 polypropylene continuous suture, and 7-0 polypropylene suture was used for the saphenous vein and radial artery grafts. All proximal anastomoses of the radial artery grafts were constructed with 7-0 polypropylene suture, and those of the saphenous vein grafts were constructed with 6-0 polypropylene suture.

The method of exposure and stabilization to perform the distal coronary anastomoses used a previously described technique. ${ }^{19}$ Off pump coronary artery bypass grafting was performed with the Medtronic Octopus 3 or 4 or Evolution stabilizing device (Medtronic, Minneapolis, Minn) for target coronary artery stabilization. The target arteries were accessed by deep pericardial traction sutures or the use of a Medtronic Starfish heart positioner (Medtronic). An intracoronary shunt (Medtronic, Grand Rapids, Mich) was used in all vessels measuring more than $1.25 \mathrm{~mm}$ in diameter while constructing the coronary anastomosis. Visualization of the anastomotic area was enhanced using a humidified carbon dioxide blower/mister (Medtronic, Grand Rapids) to disperse the blood from the anastomotic site while constructing the distal anastomoses. For safety, a cardiopulmonary bypass machine was kept on standby with a circuit mounted but not primed.

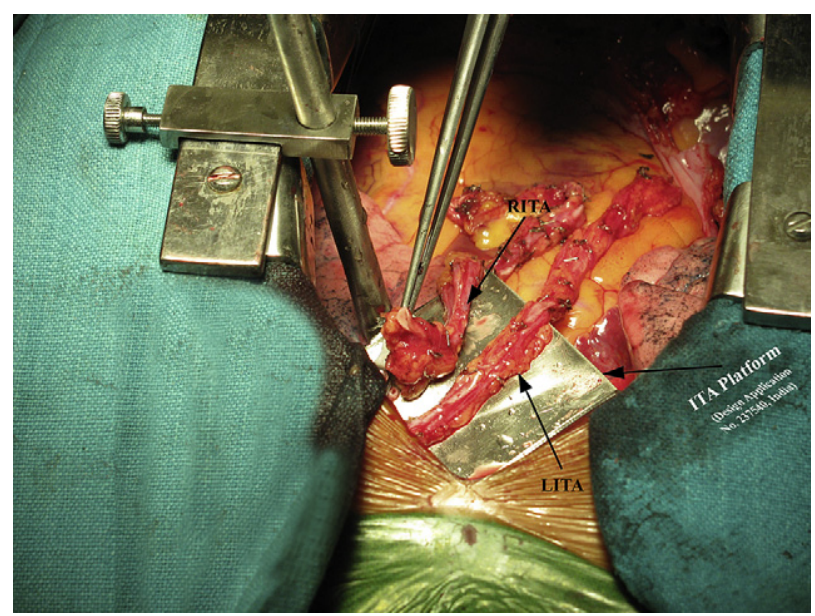

FIGURE 2. Technique of construction of left internal thoracic artery (LITA) and right ITA (RITA) "Y" graft on stable ITA anastomosis platform mounted on sternal spreader. ITA, Internal thoracic artery.

\section{Statistical Analysis}

Statistical analysis was performed with SAS, version 9.2 (SAS Institute, Cary, NC), software. Continuous variables are expressed as the mean $\pm \mathrm{SD}$, and categorical variables are expressed as percentages. A comparison of the continuous variables between groups was performed with analysis of variance. In situations in which variations between groups are significant on analysis of variance, a pairwise comparison was done by 2 -sample $t$-test. Categorical variables were analyzed using the chi-square test or Fisher's exact test. The chi-square test of independence for 4 groups was done to test the difference among the groups. Whenever the variables were not significantly different among the groups, pairwise comparisons were not performed. Multiple linear regression analysis was done to determine the effects of the baseline variables on the incidence of sternal wound infections.

\section{RESULTS}

No significant differences were present in the preoperative characteristics. The mean age was 57.8 years versus 58.3 , 57.6, and 58.3 years $(P=.6822)$, and 157 patients $(86.7 \%)$ were men versus $894(86.8 \%), 140(86.9 \%)$, and 1475 $(86.8 \% ; P=.9996)$ in groups 1 through 4 , respectively. The preoperative angina class was 3 or greater in 65 patients $(35.9 \%)$ versus $414(40.2 \%), 63(39.1 \%)$, and $654(38.8 \%$; $P=.7182)$. The left ventricular dysfunction was $40 \%$ or less in 18 patients $(9.9 \%)$ versus $104(10.0 \%), 17(10.1 \%)$, and $171(10.0 \% ; P=.9974)$, renal dysfunction (serum creatinine $>1.3 \mathrm{mg})$ was present in 71 patients $(39.2 \%)$ versus 401 $(38.9 \%), 63(39.1 \%)$, and $662(38.9 \% ; P=.9998)$, the smoking history was positive for 42 patients $(23.2 \%)$ versus $237(23.0 \%), 37(22.9 \%)$, and $391(23.0 \% ; P=.9999)$ among the 4 groups. Finally, chronic obstructive pulmonary disease was present in $29(16.0 \%)$ versus $164(15.9 \%), 26$ $(16.1 \%)$, and $272(16.0 \% ; P=.9998)$ in the 4 groups (Table 1). The prevalence of type I diabetes, the use of oral hypoglycemic agents, and the proportion of patients using insulin were similar between groups 1 and 2. No significant difference was found in the incidence of postoperative myocardial infarction $(P=.4554)$, the use of intra-aortic balloon 
TABLE 1. Preoperative patient characteristics

\begin{tabular}{|c|c|c|c|c|c|}
\hline Variable & $\begin{array}{c}\text { Group } 1 \text { (diabetes, } \\
\text { BITA grafts; } \mathbf{n}=\mathbf{1 8 1} \text { ) }\end{array}$ & $\begin{array}{c}\text { Group } 2 \text { (diabetes, } \\
\text { SITA grafts; } \mathbf{n}=\mathbf{1 0 3 0})\end{array}$ & $\begin{array}{l}\text { Group } 3 \text { (nondiabetes, } \\
\text { BITA grafts; } \mathbf{n}=161 \text { ) }\end{array}$ & $\begin{array}{l}\text { Group } 4 \text { (nondiabetes, } \\
\text { SITA grafts; } n=1700 \text { ) }\end{array}$ & $P$ value \\
\hline Age (y) & $57.8 \pm 8.52$ & $58.3 \pm 8.42$ & $57.6 \pm 7.9$ & $58.3 \pm 8.76$ & .6822 \\
\hline Men & $157(86.7)$ & $894(86.8)$ & $140(86.9)$ & $1475(86.8)$ & .9996 \\
\hline Hypertension & $43(23.7)$ & $237(23.0)$ & 37 (22.9) & $392(23.0)$ & .9969 \\
\hline Angina class $\mathrm{CCS} \geq 3$ & $65(35.9)$ & $414(40.2)$ & $63(39.1)$ & $654(38.8)$ & .7182 \\
\hline Preoperative MI & $52(28.7)$ & $296(28.7)$ & $47(29.2)$ & $486(28.6)$ & .9986 \\
\hline LVEF $\leq 40 \%$ & $18(9.9)$ & $104(10.0)$ & $17(10.1)$ & $171(10.0)$ & .9974 \\
\hline Serum creatinine $>1.3 \mathrm{mg}$ & $71(39.2)$ & $401(38.9)$ & $63(39.1)$ & $662(38.9)$ & .9998 \\
\hline Smoking history & $42(23.2)$ & $237(23.0)$ & $37(22.9)$ & $391(23.0)$ & .9999 \\
\hline COPD & $29(16.0)$ & $164(15.9)$ & $26(16.1)$ & $272(16.0)$ & .9998 \\
\hline BMI $\left(\mathrm{kg} / \mathrm{m}^{2}\right)$ & 25.48 & 25.98 & 25.94 & 25.62 & .08 \\
\hline
\end{tabular}

Data presented as mean \pm standard deviation or n (\%). BITA, Bilateral internal thoracic artery; SITA, single internal thoracic artery; CCS, Canadian Cardiovascular Society; $M I$, myocardial infarction; $L V E F$, left ventricular ejection fraction; $C O P D$, chronic obstructive pulmonary disease; $B M I$, body mass index.

pump support $(P=.2175)$, the need for postoperative dialysis $(P=.5979)$, or the incidence of postoperative cerebrovascular accidents $(P=.6749)$ among the 4 groups (Table 2). No significant difference was found in the incidence of pulmonary complications among the 4 groups (Table 2). However, the requirement for blood transfusion among the patients with BITA grafting was significantly greater than for those with SITA grafting $(P=.0001$; Table 2$)$. The intraoperative variables were similar among all 4 groups, except that the total operative time was longer for the BITA groups (groups 1 and 3$)$ than for the SITA groups $(P=.0001$; Table 3$)$. The frequency of use of in situ RITA grafts and LITA and RITA " $Y$ " grafts between groups 1 and 3 was comparable $(P=.9092)$. No statistically significant difference was seen in the incidence of pulmonary complications between the BITA and SITA harvest groups $(P>.05)$.

Superficial sternal wound complications developed in 2 patients $(1.1 \%)$ in group 1,17 patients $(1.65 \%)$ in group 2, 3 patients $(1.86 \%)$ group 3 , and 28 patients $(1.65 \%)$ group $4(P=.9941)$. Deep sternal infections occurred in 1 patient $(0.55 \%)$ in group 1,5 patients $(0.48 \%)$ in group 2,1 patient $(0.62 \%)$ in group 3 , and 14 patients $(0.82 \%)$ in group 4 . The incidence of superficial and deep sternal wound infections in those with and without diabetes and stratified by BITA and SITA harvesting is listed in Table 4. No significant difference was found in the rates of sternal wound infections, either superficial or deep, in diabetic and nondiabetic patients receiving BITA grafts or diabetic and nondiabetic patients receiving SITA grafts $(P=.9941$ and $P=.8380$, respectively). No significant difference was seen in the preoperative body mass index (BMI) between the SITA (mean BMI, $25.98 \pm 5.03 \mathrm{~kg} / \mathrm{m}^{2}$ ) and BITA (mean BMI, $\left.24.48 \pm 3.71 \mathrm{~kg} / \mathrm{m}^{2}\right)$ groups $(P=.0844)$. No significant difference was seen in the mean BMI between those who developed a sternal wound infection (mean BMI, $24.86 \pm 3.13 \mathrm{~kg} / \mathrm{m}^{2}$ ) and those who did not (mean BMI, $25.94 \pm 4.92 \mathrm{~kg} / \mathrm{m}^{2} ; P=.89$ ).

\section{DISCUSSION}

It has been well established that the ITA is the most reliable graft in patients undergoing CABG because of the excellent long-term patency rates. ${ }^{1,2}$ Compared with saphenous vein bypass grafting, patients who receive an ITA to the left anterior descending artery survive longer and experience less hospitalization for cardiac events, lower rates of cardiac reoperation, and less frequent myocardial infarction. ${ }^{1}$ Recent evidence has also indicated that BITA grafting further improves survival and reduces the need for repeat revascularization, but none of these studies were randomized. ${ }^{2-5}$ Lytle and colleagues ${ }^{2}$ attempted to address the possible selection bias using propensity score matching of patients undergoing SITA and BITA grafting

TABLE 2. Postoperative outcomes

\begin{tabular}{|c|c|c|c|c|c|}
\hline Variable & $\begin{array}{c}\text { Group } 1 \text { (diabetes, } \\
\text { BITA grafts; } \mathbf{n}=181 \text { ) }\end{array}$ & $\begin{array}{c}\text { Group } 2 \text { (diabetes, } \\
\text { SITA grafts; } \mathbf{n}=\mathbf{1 0 3 0})\end{array}$ & $\begin{array}{l}\text { Group } 3 \text { (nondiabetes, } \\
\text { BITA grafts; } \mathbf{n}=161 \text { ) }\end{array}$ & $\begin{array}{l}\text { Group } 4 \text { (nondiabetes, } \\
\text { SITA grafts; } n=1700 \text { ) }\end{array}$ & $\begin{array}{c}\text { Yates' } \\
P \text { value } \\
\end{array}$ \\
\hline Postoperative MI & 0 & $9(0.87)$ & 0 & $21(1.23)$ & .4554 \\
\hline IABP use & 0 & $11(1.06)$ & 0 & $28(1.64)$ & .2175 \\
\hline Postoperative dialysis & 0 & $7(0.68)$ & 0 & $17(1.0)$ & .5979 \\
\hline Postoperative CVA & 0 & $6(0.58)$ & 0 & $15(0.88)$ & .6749 \\
\hline Re-exploration for bleeding & $1(0.55)$ & $11(1.06)$ & $1(0.62)$ & $32(1.88)$ & .3255 \\
\hline Pulmonary complications & 2 & 12 & 1 & 19 & .98 \\
\hline Mortality & 0 & 3 & 0 & 9 & .8784 \\
\hline Blood transfusion* (n) & $176(97.2)$ & $732(71.1)$ & $158(98.1)$ & $1205(70.9)$ & .0001 \\
\hline
\end{tabular}

Data presented as n (\%). BITA, Bilateral internal thoracic artery; SITA, single internal thoracic artery; $M I$, myocardial infarction; IABP, intra-aortic balloon pump; $C V A$, cerebrovascular accident. *Pairwise $P$ values: group 1 vs $2, P=.0001$; group 1 vs $3, P=.8495$; group 1 vs $4, P=.0001$. 
TABLE 3. Intraoperative variables among groups

\begin{tabular}{|c|c|c|c|c|c|c|}
\hline Variable & $\begin{array}{c}\text { Group } 1 \text { (diabetes, } \\
\text { BITA grafts; } n=181 \text { ) }\end{array}$ & $\begin{array}{c}\text { Group } 2 \text { (diabetes, } \\
\text { SITA grafts; } \mathbf{n}=1030)\end{array}$ & $\begin{array}{l}\text { Group } 3 \text { (nondiabetes, } \\
\text { BITA grafts; } \mathbf{n}=161 \text { ) }\end{array}$ & $\begin{array}{l}\text { Group } 4 \text { (nondiabetes, } \\
\text { SITA grafts; } n=1700 \text { ) }\end{array}$ & $\begin{array}{c}P \\
\text { Value }\end{array}$ & $\begin{array}{l}\text { Pairwise } \\
P \text { value }\end{array}$ \\
\hline Total operating time $(\mathrm{min})$ & $212.4 \pm 61.5$ & $181.6 \pm 62.3$ & $209.3 \pm 64.8$ & $178.4 \pm 60.3$ & .0000 & \\
\hline Grafts/patient (n) & $3.2 \pm 0.89$ & $3.11 \pm 1.2$ & $3.2 \pm 0.68$ & $3.3 \pm 1.08$ & .3355 & \\
\hline RITA in situ grafts & $54(29.8)$ & - & $48(29.8)$ & - & .9092 & .9092 \\
\hline LITA and RITA "Y" grafts & $127(70.2)$ & - & $113(70.2)$ & - & .9092 & .9092 \\
\hline
\end{tabular}

Data presented as mean \pm standard deviation or $\mathrm{n}(\%)$. BITA, Bilateral internal thoracic artery; SITA, single internal thoracic artery; RITA, right internal thoracic artery; LITA, left internal thoracic artery.

and concluded that the use of BITA conduits significantly and independently decreased long-term death, reoperation, and angioplasty.

Despite accumulating evidence of prolonged survival and decreased cardiac events, many surgeons avoid BITA grafting because of the increased risk of sternal wound infection, especially in patients with diabetes. ${ }^{7,8,10}$ Harvesting of ITAs is considered to be associated with impairment of sternal perfusion, and the increased risk of sternal infection after BITA grafting is most usually caused by sternal ischemia. ${ }^{13,20}$ BITA harvesting carries a greater risk of sternal infection than harvesting a SITA, but the skeletonization of both ITAs significantly decreases this risk of deep sternal infection. ${ }^{21,22}$ Deep sternal wound infection is a dreaded complication that portends an increased risk of morbidity and mortality. ${ }^{7}$ Peterson and colleagues ${ }^{15}$ demonstrated that patients who develop deep sternal wound infection have a threefold increase in intensive care unit and hospital length of stay and a threefold increase in mortality. In the present study, the requirement for homologous blood transfusion in the BITA harvest group was greater than that in the SITA group and might have resulted from lower baseline hemoglobin in our patient population (mean hemoglobin, $11.2 \mathrm{~g} / \mathrm{dL}$ ). The BITA harvest was associated with more blood loss during the harvest and during the postoperative period compared with SITA harvesting.

Several clinical and laboratory studies have demonstrated reduced ipsilateral sternal blood flow after pedicled ITA harvesting. ${ }^{13,23,24}$ Skeletonization of ITA conduits results in less reduction of sternal blood flow. ${ }^{14,17}$ In contrast, a few other studies have reported no difference in the incidence of sternal wound infection between patients

TABLE 4. Incidence of sternal wound infection

\begin{tabular}{lcc}
\hline & \multicolumn{2}{c}{ Infection } \\
\cline { 2 - 3 } Group & Superficial & Deep \\
\hline 1 (Diabetes, BITA grafts; $\mathrm{n}=181)$ & $2(1.1)$ & $1(0.55)$ \\
2 (Diabetes, SITA grafts; $\mathrm{n}=1030)$ & $17(1.65)$ & $5(0.48)$ \\
3 (Nondiabetes, BITA grafts; $\mathrm{n}=161)$ & $3(1.86)$ & $1(0.62)$ \\
4 (Nondiabetes, SITA grafts; $\mathrm{n}=1700)$ & $28(1.65)$ & $14(0.82)$ \\
$P$ value & .9941 & .8380 \\
\hline
\end{tabular}

Data presented as $\mathrm{n}(\%)$. BITA, Bilateral internal thoracic artery; SITA, single internal thoracic artery. with skeletonized ITA and conventional pedicled ITA. ${ }^{25,26}$ Anatomic studies have revealed that sternal and anterior intercostal branches of the ITA originate either directly or as a common trunk from the ITA and substantial collateral flow to the sternum can be maintained in the absence of the ITA, provided the sternal anterior intercostal trunks are left intact. ${ }^{16}$ Skeletonization of the ITA often results in preservation of these common trunks.

Although experimental evidence has suggested that the harvest technique can affect the sternal blood supply after harvesting of the ITAs, the effect of ITA harvesting on the sternal blood supply in human subjects is not completely understood. It was recently reported that the degree of damage to the sternal microcirculation after ITA harvesting was not different between the skeletonized and pedicled groups, suggesting that skeletonization is not advantageous for maintaining sternal microcirculation. ${ }^{27}$ Moreover, skeletonization might be technically more difficult than pedicled ITA harvesting and might increase the risk of conduit injury. It is a relatively new surgical technique; therefore, current data on long-term patency are not available. Also, even the skeletonization technique of ITA harvesting did not completely protect from sternal wound infection after BITA dissection. ${ }^{9}$ In addition, the off-pump technique of coronary $\mathrm{CABG}$ has been associated with a reduction of poststernotomy infections in diabetic patients undergoing myocardial revascularization. ${ }^{9}$

Anastomoses among the following arteries might possibly promote the development of collateral circulation to the sternum after the BITA harvest. The pericardiacophrenic artery ends by anastomosing with the musculophrenic and phrenic arteries. The musculophrenic artery gives the anterior intercostals arteries for the 7th, 8th, and 9 th intercostals spaces and anastomoses with the posterior intercostal arteries arising from the descending thoracic aorta. Also, along its course through the diaphragm it anastomoses with the phrenic artery. The superior epigastric artery ends by anastomosing with the inferior epigastric branch of the external iliac artery. Application of the principle of preservation of the communicating musculophrenic and superior epigastric arteries to the chest wall and preservation of pericardiacophrenic artery during the skeletonized technique of ITA harvest might further preserve the sternal blood supply. 
The present study was limited by the observational, nonrandomized design with potential confounding information and selection bias. As is true for any observational study, we were unable to account for the influence of any unmeasured factors on the risk of postoperative sternal wound infection. Propensity matching was not used in the statistical analysis. The present study also did not contain information on the objective assessment of the collateral blood supply to sternum after BITA or SITA harvesting.

\section{CONCLUSIONS}

This modification of the pedicled harvesting technique by preserving the communicating musculophrenic and superior epigastric arteries to the chest wall and preservation of the pericardiacophrenic artery and the sternal intercostal trunks of the ITA possibly promotes the collateral circulation to the sternum and presternal tissues after BITA harvest; thereby reducing the incidence of sternal wound infection. In addition, the off-pump technique of coronary revascularization might also contribute to the reduction in sternal wound infections after BITA harvesting. Additional randomized comparisons of standard pedicled harvesting and modified pedicled harvesting is needed to confirm or refute the clinical advantages of this modification of pedicled harvesting.

We thank A. Nadamuni Naidu, MSc (Stat), Head, Department of Statistics (Retired), National Institute of Nutrition, ICMR, Hyderabad, India, for statistical advice and analysis for this study; and Dr Antony L. Basile, MS, FMRF, Medical Director, Star Hospitals, Hyderabad, India and B. Prashanthi, MSc (Clinical Research), Clinical Coordinator, Star Hospitals, Hyderabad, India, for the help in preparing our report.

\section{References}

1. Loop FD, Lytle BW, Cosgrove DM, Stewart RW, Goormastic M, Williams GW, et al. Influence of the internal mammary artery graft on 10-year survival and other cardiac events. N Engl J Med. 1986;314:1-6.

2. Lytle BW, Blackstone EH, Loop FD, Houghtaling PL, Arnold JH, Akhrass R, et al. Two internal thoracic artery grafts are better than one. J Thorac Cardiovasc Surg. 1999;117:855-72.

3. Buxton BF, Komeda M, Fuller JA, Gordon I. Bilateral internal thoracic artery grafting may improve outcome of coronary artery surgery: risk-adjusted survival. Circulation. 1998;98(Suppl):III-1-6.

4. Taggart DP, D'Amico R, Altman DG. Effect of arterial revascularization on survival: a systematic review of studies comparing bilateral and single internal mammary arteries. Lancet. 2001;356:870-5.

5. Rizzoli G, Shiavon L, Bellini P. Does the use of bilateral internal mammary artery (IMA) graft provide incremental benefit relative to the use of single IMA graft? Eur J Cardiothorac Surg. 2002;22:781-6.

6. Kurlansky PA, Traad EA, Dorman MJ, Galbut DL, Zucker M, Ebra G, et al. Thirty-year follow-up defines survival benefit for second internal mammary artery in propensity-match groups. Ann Thorac Surg. 2010;90:101-8.

7. Loop FD, Lytle BW, Cosgrove DM, Mahfood S, McHenry MC, Goormastic M, et al. J. Maxwell Chamberlain memorial paper: sternal wound complications after isolated coronary artery bypass grafting: early and late mortality, morbidity, and cost of care. Ann Thorac Surg. 1990;49:179-87.

8. Grossi EA, Esposito R, Harris LJ, Crooke GA, Galloway AC, Colvin SB, et al. Sternal wound infections and use of internal mammary artery grafts. $J$ Thorac Cardiovasc Surg. 1991;102:342-6.

9. Nakano J, Okabayashi H, Hanyu M, Soga Y, Nomoto T, Arai Y, et al. Risk factors for wound infection after off-pump coronary artery bypass grafting: should bilateral internal thoracic arteries be harvested in patients with diabetes? $J$ Thorac Cardiovasc Surg. 2008;135:540-5.

10. Lytle BW. Skeletonized internal thoracic artery grafts and wound infection. J Thorac Cardiovasc Surg. 2001;121:625-7.

11. Arnold M. The surgical anatomy of sternal blood supply. J Thorac Cardiovasc Surg. 1972;64:596-610.

12. Seyfer AE, Shriver CD, Miller TR, Graeber GM. Sternal blood flow after median sternotomy and mobilization of the internal mammary arteries. Surgery. 1988; 104:899-904.

13. Carrier M, Gregoire J, Tronc F, Cartier R, Leclerc Y, Pelletier LC, et al. Effect of internal mammary artery dissection on sternal vascularization. Ann Thorac Surg. 1992;53:115-9.

14. Parish MA, Asai T, Grossi EA, Esposito R, Galloway AC, Colvin SB, et al. The effects of different techniques of internal mammary artery harvesting on sternal blood flow. J Thorac Cardiovasc Surg. 1992;104:1303-7.

15. Peterson MD, Borger MA, Rao V, Peniston CM, Feindel CM. Skeletonization of bilateral internal thoracic artery graft lowers the risk of sternal infection in patients with diabetes. J Thorac Cardiovasc Surg. 2008;126:1314-9.

16. Henriquez-Pino JA, Gomes WJ, Prates JC, Buffolo E. Surgical anatomy of the internal thoracic artery. Ann Thorac Surg. 1997;64:1041-5.

17. Cohen AJ, Lockman J, Lorberboym M, Bder O, Cohen N, Medalion B, et al. Assessment of sternal vascularity with single photon emission computed tomography after harvesting of the internal thoracic artery. J Thorac Cardiovasc Surg. 1999;118:496-502.

18. Sajja L. Reduction of sternal wound infection in diabetic patients undergoing bilateral internal thoracic artery grafting: does the technique of harvest matter? Heart Surg Forum. 2010;13(Suppl):S143.

19. Sajja LR, Mannam G, Sompali S, Reddy KV, Ravirala BR, Raju BS, et al. Does multi-vessel off-pump coronary artery bypass grafting reduce post operative morbidity compared to on-pump CABG? Ind J Thorac Cardiovasc Surg. 2004 20:173-7.

20. Matsa M, Paz Y, Gurevitch J, Shapira I, Kramer A, Pevny D, et al. Bilateral skeletonized internal thoracic artery grafts in patients with diabetes mellitus. J Thorac Cardiovasc Surg. 2001;121:668-74.

21. De Paulis R, De Notaris S, Scaffa R, Nardella S, Zeitani J, Del Giudice C, et al. The effect of bilateral internal thoracic artery harvesting on superficial and deep sternal infection: the role of skeletonization. J Thorac Cardiovasc Surg. 2005; 129:536-43

22. Peterson MD, Borger MA, Rao V, Peniston CM, Christopher M, et al. Skeletonization of bilateral internal thoracic artery grafts lowers the risk of sternal infection in patients with diabetes. J Thorac Cardiovasc Surg. 2003;126: 1314-9.

23. Calafiore AM, Contini M, Vitolla G, Di Mauro M, Mazzei V, Teodori G, et al. Bilateral internal thoracic artery grafting: long term clinical and angiographic results of in situ versus Y grafts. J Thorac Cardiovasc Surg. 2000; 120:990-8.

24. Cunningham JM, Gharavi MA, Fardin R, Meek RA. Considerations in the skeletonization technique of internal thoracic artery dissection. Ann Thorac Surg. 1992;54:947-50.

25. Ura M, Sakata R, Nakayama Y, Arai Y. Bilateral pedicled internal thoracic artery grafting. Eur J Cardiothoracic Surg. 2002;21:1051-9.

26. Pevni D, Mohr R, Lev-Run O, Locer C, Paz Y, Karmer A, et al. Influence of bilateral skeletonized harvesting on occurrence of deep sternal infection in 1000 consecutive patients undergoing bilateral internal thoracic artery grafting. Ann Surg. 2003;237:277-80.

27. Nishi H, Mitsuno M, Tanaka H, Ryomoto M, Fukui S, Miyamoto Y, et al. Decreasing sternal microcirculation after harvesting the internal thoracic artery. Eur J Cardiothorac Surg. 2011;40:240-4. 